Article Type: Research Paper

\title{
Factors Influencing the Households' Adaptation under Natural Disaster Risk in the Coastal Areas of Giao Thien, Giao Thuy, Nam Dinh, Vietnam
}

\author{
Nguyen Thanh Phong*1, Nguyen Ngoc Mai ${ }^{1}$, and Satit Aditto ${ }^{2}$
}

\section{OPEN}

AFFILIATION:

${ }^{1}$ Vietnam National University of Agriculture, Ha Noi, Vietnam.

${ }^{2}$ Khon Kaen University, Khon Kaen, Thailand.

\section{*CORRESPONDENCE:}

ntphong@vnua.edu.vn

THIS ARTICLE IS AVALILABLE IN:

http://journal.umy.ac.id/index.php/esp

DOI: $10.18196 /$ jesp.21.1.5034

\section{CITATION:}

Phong, N. T., Mai, N. N., \& Aditto, S. (2020). Factors Influencing the Households' Adaptation Under Natural Disaster Risk in the Coastal Areas of Giao Thien, Giao Thuy, Nam Dinh, Vietnam. Jurnal Ekonomi \& Studi Pembangunan, 21(1), 105-124.

\section{ARTICLE HISTORY}

\section{Received:}

22 January 2020

Reviewed:

6 March 2020

16 April 2020

Revised:

17 March 2020

19 April 2020

Accepted:

21 April 2020
Abstract: This research is to identify the impacts of natural disaster risk on households of local residents and to identify the adaptation of households with natural disaster risk in Giao Thien commune, Giao Thuy district, Nam Dinh province, Vietnam. Both qualitative and quantitative methods are applied in this study to assess the overall impact of disasters on the livelihood strategies of households in response to natural disaster. The findings show that the risks of natural disasters affecting the livelihood of the local population in the study area are typhoons, floods, coastal erosion/ sea level rise, and saltwater intrusion. Currently, people in the researching area are not merely affected by one disaster but usually 2-3 or even 4 types of disasters in a short period of time. Therefore, this leads to economic losses, in the form of assets of the households. There are 6 solutions to cope with disaster risks that people often used to reduce the damage include: (1) regularly monitor information; (2) Change season calendar; (3) Change crop varieties; (4) Buy insurance; (5) Save of fertilizer and pesticide inputs; (6) Save seed production.

Keywords: Household's adaptation; Natural disaster risk; Economic losses; Agriculture and environment.

JEL Classification: Q54; Q51; Q15.

\section{Introduction}

On the basis of common standards for risk management between Australia and New Zealand (AS / NZS 4360: 1995), Hardaker (1997) introduced the concept that "risk management Rola systematic adoption management policies, principles and actions of formats, analysis, evaluation, treatment, and monitoring of risk in order to minimize losses and maximize opportunities". However, these guidelines are not fixed and adaptive to each particular case (Hardaker, 1997). With the concept of risk management strategies and tools used to manage risk. Newbery (1989) introduced the concept that the "strategic risk management is a structured approach closely and legacy in the identification, assessment, and risk management". Accordingly, strategies Newbery gave 3 basic risk management including risk sharing, concentration and dispersion of risk, and risk diversification. Disaster risks are the diverse and complex impacts 
Factors Influencing the Households' Adaptation Under Natural Disaster Risk ...

on many areas of life (Sales, 2009; Roshanka \& Ruben, 2018). For example, the earthquake could affect human settlements by ash, lava eruptions, mudslides, floods, forest fires (Warrick, 1980) or tropical storm can cause casualties and the destruction by wind, rain, storms and flooding in the mainland (Bryant, 1993; Hiwasaki, Lunab, Syamsidikc, Shawd, 2014).

According to the UNDP (2015), Vietnam has 9 major natural disasters that it suffers from. They include hurricanes, tornados hail, surges, landslides, monsoon, cold air floods, floods, and storms (Chaudhry \& Ruysschaert, 2007). Damage caused by natural disasters every year in Vietnam is extremely large (McElwee, 2010). According to the Committee for Flood and Storm Control (2009), the total damage caused by natural disasters is estimated at 23,745 billion VND, including storm damage of 16,078 billion VND. In recent, natural disasters affected 39,881 households displaced. In 2009, there were 26,778 households displaced by natural disasters (including households affected by the storm). Viet Nam is extremely vulnerable to climate change impacts given its extensive coastline and river deltas, and highlands that have poor water retention capacity and are susceptible to severe erosion (Nhu, Thuy, Wilderspin, \& Coulier, 2015).

As a coastal area located in the low-lying Red River Delta, the province Nam Dinh is affected and exposed to the direct impacts of climate change such as sea-level rise, extreme weather phenomena, temperature and rainfall pattern change, and salinity intrusion. Sea level rise changes the patterns of sea currents and sedimentation in coastal areas. Additionally, the permanent inundation zone, lowland and coastal natural systems such as mangroves and other wetlands would be affected by the sea level rise and the associated changes in biophysical and chemical conditions. The area is prone to the coastal impacts of extreme weather phenomena. During the storm, high tides and waves caused landslides, broken segments, dikes, embankments, and culverts, as the result, several hectares of rice field was damaged. Most of the huts on the clam farming areas in the district were washed away. High tides caused water levels to reach a height of 2.65 $\mathrm{m}$, the highest tides within the last 40 years. Extreme weather events, particularly typhoons, affect clam operations. Storms accompanied by heavy rainfall lead to a sudden decrease in salinity, and if rainfall is large enough, clams will die because of excess levels of freshwater (Sajise, Ramirez, Zamora, Herbosa, Agbon, \& Nguyen, (2017); ADPC, 2003).

The research makes new contribution to the literature: A summary of data used to multistage sampling method 95 households, which adapted to natural disasters; A brief review of various types and sources of data for adaptation of household to each disaster in the study area. The findings showed the risk of natural disasters affecting the livelihood of the local population are typhoons, floods, coastal erosion/ sea level rise, and saltwater intrusion. They had been using 6 solutions to cope with disaster risks. 


\section{Research Method}

The qualitative research used in this study is the essence of human experiences, which is described by participants in the study. The study tries to get the understanding of experience in the adaptation with natural disaster risks used by households and what kind of the problems that households mostly confront marks phenomenology as a philosophy as well as method, and technique associated with the studying a small number of subjects. Sometimes, the researcher uses owned experiences in order to understand those participants in the study (Creswell, 2003; Kleinbaum, Kupper, Muller, \& Nizam, 1998).

The research used a multi-stage sampling design to survey households in Giao Thien, Giao Thuy, Vietnam, how the household respond to risk towards typhoons, floods, coastal erosion/ sea level rise, and saltwater intrusion. The district has 21 communes and 2 municipalities, of which 10 villages along the coast. The sampling selected random 95 households from 10 villages in a coastal area in Giao Thien commune, Giao Thuy district, Vietnam, who were then administered questionnaires. The secondary data was collected from the province, district and commune levels through natural condition reports, annual social-economic reports in 2018, damage reports, related documents from NGOs and mass organizations working in the commune. After collecting data from various methods, the data were analyzed using Stata 13 and Excel 2013 statistical packages.

To evaluate the factors affecting the decision of the households, we use Logit model. In many practical applications, Logit model is used in order to determine the factors that affect an individual's choice between lots of other options (Greene, 2012; Kleinbaum, Kupper, Muller, \& Nizam 1998). The decision to use these measures to respond to natural disasters including not respond to risk and respond to risk. The model of the form as follows:

$$
P\left(Y_{i}=K_{i}\right)=\frac{e^{Z}}{1+e^{Z}}
$$

Where $\mathrm{Yi}$ is the dependent variable response to the decision of the household

- $\mathrm{Yi}=0$ : if household does not respond to risks

- $\mathrm{Yi}=1$ : if household responds to risks

$$
\begin{aligned}
\mu \mathrm{Y} & =\mu \mathrm{Y}(\mathrm{x} 1, \mathrm{x} 2, \mathrm{x} 3, \mathrm{x} 4, \mathrm{x} 5, \mathrm{x} 6, x 7, \mathrm{x} 8) \\
& =\beta 0+\beta 1 \times 1+\beta 2 \times 2+\beta 3 \times 3+\beta 4 \times 4+\beta 5 \times 5+\beta 6 \times 6+\beta 7 \times 7+\beta 8 \times 8
\end{aligned}
$$

The random errors ei are usually assumed to be independent of each other and follow a normal distribution with mean 0 and variance are $\sigma 2$. 
Factors Influencing the Households' Adaptation Under Natural Disaster Risk ...

Table 1 The definition variables of model Logit

\begin{tabular}{|c|c|c|}
\hline No & Independent variables & Illuminate \\
\hline 1 & Formal institutions (FI) & $\begin{array}{l}\text { The number of organizations that family's } \\
\text { members engage }\end{array}$ \\
\hline 2 & Informal institutional (II) & The number of close friends \\
\hline 3 & The number of labors in the household (LB) & Person \\
\hline 4 & $\begin{array}{l}\text { The age of the household's head or decision- } \\
\text { maker about coping in the family (AG) }\end{array}$ & Years \\
\hline 5 & Gender (G) & Dummy variables (0: Male, 1: Female) \\
\hline 6 & The level of education (ED) & $\begin{array}{l}\text { Dummy variables ( } 0=\text { under High school and } \\
\text { High school, } 1=\text { higher than High school) }\end{array}$ \\
\hline 7 & Land use for agriculture (LA) & $\mathrm{m} 2$ \\
\hline 8 & Income per year (IC) & million VND \\
\hline
\end{tabular}

\section{Result and Discussion}

1. Impacts of natural disaster risk on the households in the coastal areas in Giao Thien, Giao Thuy, Nam Dinh, Vietnam

The climate change took and caused strong fluctuations through extreme weather events, anomalies. The natural disaster situation in Vietnam also happens more often, more complicated and caused serious consequences for people's lives, especially poor people. According to a report on The Global Climate Risk, 2010, published by the organization German Watch, Vietnam is a country ranked 4th in the world for damage caused by the impact of extreme climate events and forecasts for 30 years to Vietnam will be the $13^{\text {th }}$ of 170 countries and be belonging to a special group risk countries (UNDP, 2015).

The World Bank showed the type of disaster damage to people and the largest economy in Vietnam, including storms and floods. Besides drought is one of the natural disasters affecting large numbers of the population (UNISDR, 2013).

Giao Thien commune has an area of $7.88 \mathrm{~km}^{2}, 2752$ households. The commune has 14 villages, of which 10 villages locate along the coast, namely 17, 19, 21, 22, 24, 25, 27, 28, 29, and 30. The commune has 1660 households locate along the coast. Through the process of practical research, in Giao Thien, the types of natural disasters occur mainly: flooding, typhoon, coastal erosion/sea level rise, and saltwater intrusion.

Table 2 showed the distribution of households affected by the disaster risks in the study area. Floods affect most of coastal households in Giao Thien, where water from the communal door runs through drainage canals to the sea, especially in the villages near the coast. During storm incidence, the water port is closed to prevent saltwater intrusion, but heavy rains cause incidences of more serious flooding. In villages in Giao Thien, a fraction 
Phong, Mai, \& Aditto

Factors Influencing the Households' Adaptation Under Natural Disaster Risk ...

Table 2 Distribution of Affected Households by Commune in 2017

\begin{tabular}{|rccccc|}
\hline Village & No. of households & $\begin{array}{c}\% \\
\text { Households } \\
\text { Affected by } \\
\text { Flooding }\end{array}$ & $\begin{array}{c}\text { \% Households } \\
\text { Affected by } \\
\text { Typhoon }\end{array}$ & $\begin{array}{c}\text { \% Households } \\
\text { Affected by } \\
\text { Coastal Erosion/ } \\
\text { Sea Level Rise }\end{array}$ & $\begin{array}{c}\text { \% Households } \\
\text { Affected by } \\
\text { Saltwater } \\
\text { Intrusion }\end{array}$ \\
\hline 17 & 10 & 8.42 & 100 & 0 & 10.53 \\
19 & 11 & 9.47 & 100 & 0 & 11.58 \\
\hline 21 & 11 & 9.47 & 100 & 0 & 11.58 \\
\hline 22 & 8 & 2.11 & 100 & 0 & 2.11 \\
\hline 24 & 6 & 1.05 & 100 & 0 & 3.16 \\
25 & 6 & 3.16 & 100 & 0 & 3.16 \\
27 & 8 & 1.05 & 100 & 0 & 5.26 \\
\hline 28 & 11 & 8.42 & 100 & 0 & 11.58 \\
\hline 29 & 13 & 13.68 & 100 & 2.11 & 13.68 \\
\hline 30 & 11 & 11.58 & 100 & 1.05 & 11.58 \\
\hline Total & 95 & $\mathbf{6 8 . 4 2}$ & 100 & $\mathbf{3 . 1 6}$ & $\mathbf{8 4 . 2 1}$ \\
\hline
\end{tabular}

Source: Author, 2018

of the percentage of coastal households surveyed (1-3\%) had been affected by the floods because the village was located in higher places, so they have less affected by rising water. Typhoons affected all selected households surveyed, especially in 2012, when the typhoon was predicted incorrect. Locals in the village were not well prepared to deal with it because it causes serious damage to the local population.

Coastal erosion is severe in Giao Thien because the commune is situated at the mouth of the Red River. On the form, three families (3.16\% of the total) in the sample reported that their fishpond dikes and local dikes eroded and collapsed. However, compared with other hazards, coastal erosion is most dramatically. The average of the surveyed households was affected unique $3.16 \%$.

Saltwater intrusion caused serious problems for families living near the sea dike. In general, a high proportion of households surveyed in Giao Thien affected with $84.21 \%$. Every year, in winter, the rice fields are abandoned and no irrigation. Water tables have dropped, this time, providing room for saltwater intrusion, groundwater and surface water can be used for the household. Therefore, in Giao Thien commune, most of the households need to build a concrete water tank to conserve water for drinking and cooking throughout the year. Also, water for washing and bath taken from contaminated surface water from nearby ponds and irrigation main channel. Saltwater intrusion caused serious problems for the households in the village number 28,29 , and 30 , which not only affects the water used for cooking and drinking but also impacts water for aquaculture soft drink. For aquaculture water becomes too salty, the fish have been observed to develop (yield decreasing) slowly, catching the red-eye problems, or die of increased salinity.

Impact from Typhoons and Flooding on households

The frequency and value of household damage from typhoons and flooding in the selected sites are showed in Table 3. 
Factors Influencing the Households' Adaptation Under Natural Disaster Risk ...

Table 3 Mean Value of Household Level Damages from Typhoons and Flooding by Commune in 2017 (Unit: 1000VNĐ, 1 USD = 23000 VNĐ).

\begin{tabular}{|cccccc}
\hline Village & $\begin{array}{c}\text { Damage/ Loss } \\
\text { to House }\end{array}$ & $\begin{array}{c}\text { Loss in Agricultural } \\
\text { Production }\end{array}$ & $\begin{array}{c}\text { Loss in } \\
\text { Fishing } \\
\text { Income }\end{array}$ & $\begin{array}{c}\text { Loss in } \\
\text { Aquaculture } \\
\text { Production }\end{array}$ & Other \\
\hline 17 & 6700 & 5400 & 4500 & 0 & 2000 \\
19 & 5500 & 4900 & 4390 & 0 & 2100 \\
21 & 7800 & 4300 & 5700 & 0 & 2000 \\
22 & 5400 & 9200 & 24000 & 0 & 2500 \\
24 & 4100 & 8000 & 30500 & 0 & 2400 \\
25 & 2100 & 9300 & 21200 & 0 & 3100 \\
27 & 3400 & 8100 & 32100 & 0 & 2100 \\
28 & 6000 & 4200 & 0 & 31100 & 1500 \\
29 & 6300 & 5000 & 0 & 24000 & 4000 \\
30 & 6200 & 4900 & 0 & 35000 & 3500 \\
Mean & $\mathbf{5 6 5 3}$ & $\mathbf{5 9 2 1}$ & $\mathbf{1 5 2 5 0}$ & $\mathbf{2 9 5 1 0}$ & $\mathbf{2 5 4 6}$ \\
\hline
\end{tabular}

Source: Author, 2018

\section{Damage / Loss to House}

In Giao Thien communes, the surveyed households have experienced less loss compared to those in the other area. In the sample there were 95 households, experiencing loss to the house with the average loss of 5.65 million VND. The shock was from destroyed roofs, kitchen, and frontier walls. Some households were severely affected. Notably, one household has damages amounting to more 50 million VND because their roof is destroyed and unroofed. It can be seen that before and during the risk, preparation to cope with typhoons/floods were made by people in Giao Thien commune relatively better than those in another area, therefore, they experienced less damage/loss to their houses after the disaster.

Loss in Agricultural Production

In the sample interview, there were $100 \%$ households who experienced loss in agricultural production with the average loss of 5.92 million per household. In Giao Thien commune, loss in crop production was the biggest, because farmers in this commune mostly used high-quality rice varieties like $\mathrm{BC} 15$ and sticky rice, which often required long times of farming. The typhoons were earlier than the usual, these rice fields were not yet up for harvest when the typhoon hit. In Giao Thien commune, loss in livestock production was less, because of the small scale. The local people prepared well to move animals to safer places and strengthened animal houses before and during the disaster.

Loss in Fishing Income

Losses in fishing income were higher than the losses from damage to property and agricultural production. However, there was the only household have fishing that was affected. In the sample, there were 60 households (63.16\%) with a loss in fishing income 
Factors Influencing the Households' Adaptation Under Natural Disaster Risk ...

with the average loss of 15.25 million VND per household. Early warning system worked well in the region. Fishers were able to move fishing boats and gears to safer places.

Giao Thien commune had fewer fishers so did not have a fishing port and a boat bay. Fishing boats had to be moved to the inner areas of the mangrove or safer places in other communes during time have natural disaster risk. Therefore, damages to fishing boats were usually remarkable. Fishers were not able to reach the boats during typhoons (because of distance) to pump water out or to strengthen the boats so damages to boat engine, loss of fishing gears, etc. Thus, in this commune, damages to fishing boats and gears were due to poor fishing infrastructure, fewer preparations before and during time have typhoons.

Loss in aquaculture

The mostly of households' aquaculture had ponds. The farms are concentrated in areas near estuaries and coastal areas. The majority of farming is brackish lagoons, a few are freshwater marshes and salt marshes. The results also from group discussion show that in 2013, the Giao Thien commune has converted nearly 2 hectares of rice and salt low productivity to aquaculture. Aquaculture is profitable farming areas, per capita income of nearly 300 million / ha, more than 3 times higher than rice and salt. However, there are many risks. When a disaster occurs, most of the power station is disconnected or damaged, the same time as the water mills provide oxygen for the shrimp cannot work. When it is raining heavily, it will change salinity and $\mathrm{pH}$, the alkalinity of shrimp's environment living prone to situations of shrimp, clams, dead or incubation will arise later.

Through the survey shows, there were 21 households, accounting for $22.1 \%$ of the total sample, facing loss in aquaculture with the average loss of 29.51 million VND per household because aquaculture in the selected communes was vulnerable to storm surge, flood, and typhoons. The loss in aquaculture was huge due to the large investments required in aquaculture operations and most of the fishponds are close to the central sea dike or beyond the dike. The location of ponds makes it difficult to have effective preparation methods before or during typhoons. Floods along with typhoons swiped away fish stock and pond accessories and broke pond dike etc.

Impact of Coastal Erosion/ Sea Level Rise

In these current years, coastal erosion is not a big problem in the commune since the central sea dike is strongly improved and concreted. However, erosion is still observed in some areas beyond at fishponds along the Red Riverbank in Giao Thien. The riverbank is continuously eroded and a small community living beyond the dike to the riverbank has been moved inside the dike. There were two households with losses in aquaculture about 50 million VND.

Accordingly, group discussion was showing sea level rise is observed and there were attempts to upgrade fishpond dike and pond water gate every year. It is crucial for the 
Factors Influencing the Households' Adaptation Under Natural Disaster Risk ...

fish farmers to control the salinity to protect shrimp and crab farming against the sea level rise and typhoons.

The majority of interview households recognized the loss of agricultural land due to sea level rise and related events less (57.89\%). Those household's loss of agricultural land (larger and largest) that are households living outside the dikes.

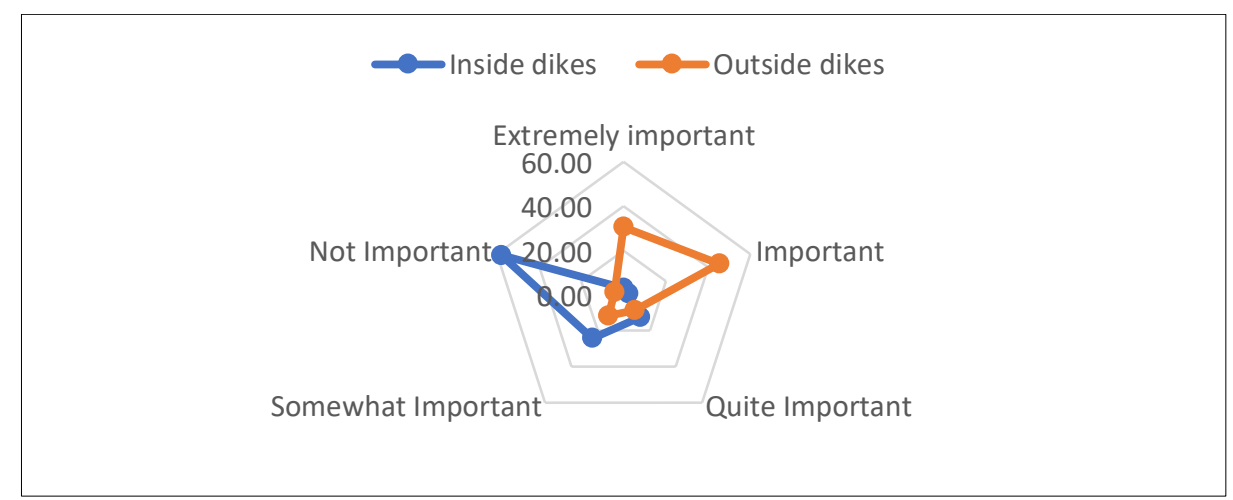

Figure 1 Loss land for agricultural production

Source: Author, 2018

The frequency and value of household damage from saltwater intrusion in the selected sites are showed in Table 4. Saltwater intrusion affected mostly agriculture and aquaculture. In the sample, $100 \%$ households experienced loss in agricultural production with the average loss of 4.5 million VND. Besides, there were 6 households' members, whose got kidney problems (with the average 5.2 million VND) and 15 households had a problem with lack of freshwater for family routines.

Table 4 Mean Value of Household Level Damages from Saltwater Intrusion by Commune in 2017 (Unit: 1000 VND)

\begin{tabular}{|cccccc}
\hline DAMAGES & $\begin{array}{c}\text { Loss in } \\
\text { Agricultural } \\
\text { Production }\end{array}$ & $\begin{array}{c}\text { Death/ Loss } \\
\text { of Livestock }\end{array}$ & $\begin{array}{c}\text { Household } \\
\text { members got } \\
\text { kidney problems }\end{array}$ & $\begin{array}{c}\text { Lack of } \\
\text { freshwater for } \\
\text { family routines }\end{array}$ & Others. \\
\hline 4,500 & 0 & 5,200 & 2,400 & 1,800 \\
$(95)$ & $(6)$ & $(15)$ & $(1)$ \\
\hline
\end{tabular}

Note: Figures in parentheses are frequency of respondents

Source: Author, 2018

Other effects

Impact on Education

According to the group discussion results support the survey findings above, the impacts of natural disaster risk on education mainly due to sea-level rise and floods, which damaged the infrastructure of schools and disrupted school-time of students. Typically, in Vietnam, children in school age which can stay at home with their parents in case of a storm, heavy flooding. However, in coastal areas, whenever a flood occurs, the damage caused by natural disasters is much greater than the other coast region. Therefore, every 
Factors Influencing the Households' Adaptation Under Natural Disaster Risk ...

time a typhoon made landfall, the school and the facilities are more severely devastated, children should stay at home for longer. In particular, there are some pupils to leave school because of relatives killed, missed or injured by the effects of typhoons, especially those students from poor households, it affected the quality of education. As mentioned above, currently the coastal households live mainly on the fishing inshore fishery. Education of local people is still very low. Children are growing up in here when the family had to go to sea fishing, so the time for learning is very short. Another side, when the typhoon hit, all the households here need to find shelter, so right after a long time when the typhoon ends, new classes can operate normal.

Impact on health

On the one hand, group discussion was talking about as a rule after the environmental disaster was a major disturbance, polluted water, which was the cause of flooded outbreaks of intestinal diseases and diseases spread by source waters (including animal diseases, natural disease outbreaks, patients from other places).

\section{Adaptation of $\mathrm{HHs}$ with natural disaster risk}

Adaptation with disaster risk in crop

Before the disaster, people have to take measures to help them mitigate the damage to production as well as infrastructure (OECD, 2008; Brammer, 2013). Measures are different for each type of disaster. However, we categorize people's measures to prevent and reduce the harmful effects of disaster risk into three main groups which include prevention measures, measures to transfer and measures to face to face risks.

For rural households, disaster risk has the greatest impact on the affected households that depend on farming. When natural disasters affect farming areas, not only production is affected but also household income. Therefore, depending on resources, their ability already has measures to reduce disaster risk for cultivating their fields. They have been used measures include regular information monitoring and change production seasonality, change varieties of plants and animals, insurance, storage of fertilizers, reserves pesticide and other inputs, reserves seed.

Regularly monitoring of information: The farmers can track weather information, seasonality that is extremely important. From time immemorial, people have been interested in the weather by monitoring the natural phenomena like the moon, the clouds, and the sun from which to make decisions related to seasonality as well as disaster prevention. Today, with the development of television, radio, books people actively seek information about seasonal weather changes. Besides local agricultural extension system, the village head, village chief propaganda also involved providing information to farmers. In addition to information about the weather, people also follow the progress of information such as the new science and technology, new drought-resistant varieties, cold weather. This is a measure to help farmers increase pro-activeness in preventing and facing disasters. However, some households still have limited understanding and access 
Factors Influencing the Households' Adaptation Under Natural Disaster Risk ...

information and use the information to prevent disaster risk reduction are limited. Therefore, through aggregated data shows that more than $85 \%$ of households regularly monitor information.

Changing season calendar: This is a simple measure but highly effective in the prevention and mitigation of disaster risk losses caused. According to the calculation that the laws of nature, weather and households change in planting date earlier or before 1 week, 2 weeks to be harvested before the stage of disaster or occurrence, or the period of the decisions important crop variety can yield avoid disaster. Some households also apply the change planting season for trees suitable for the weather to avoid disaster risk. According to survey data, the percentage of households is applying this measure very much, an average of nearly $79 \%$. The village number 19 is the highest rate (100\%) and the number second is village number 21 (nearly 90\%).

Changing seed: to shorten the cultivation or select varieties suitable for the local weather, as well as cycles of natural disasters occur locally conducted relative changes of plant varieties. Some households have switched to grow vegetables that take short days to mature instead of corn. Another difficulty when converting plant is money invested in seeds, fertilizers, and plant protection products may be more expensive and therefore fewer households apply with $31 \%$.

Buying agricultural insurance: agricultural insurance is a common form in the world to help farmers reduce the risk of natural disasters either by price fluctuations in the market (Dercon, S., 2002; Dercon, S. H. 2004). But in Vietnam, it was developed in 2011 and the insurance was pilot tested after 3 years over 300 thousand households. This figure is relatively small compared with 10 million households across the country. The causes for households hadn't been participating in agricultural insurance that was due to the propagation and promotion. Besides, farmers did not fully understand the benefits of agricultural insurance also. Also, procedures for agricultural insurance is cumbersome. People went through a lot of time-consuming steps in the acquiring membership certification. In the study area, only some households are from the projects of nongovernmental organizations to support agricultural insurance. However, the number of households to be involved are not more than $2 \%$. A measure of agricultural insurance is regarded as the most effective measure to deal with disaster risk. The measure was classified as risk transfer measures, the community supports each other in a fair manner.

Table 5 Adaptation of the households with disaster risk in crop

\begin{tabular}{lcc}
\hline $\begin{array}{c}\text { Measures of the households adapt with disaster } \\
\text { risk in crop }\end{array}$ & Frequency & Percentage (\%) \\
\hline Regularly monitor information & 81 & 85.26 \\
Seasonally adjusted production & 75 & 78.95 \\
Changing crop varieties & 15 & 15.79 \\
Buy insurance & 1 & 1.05 \\
Reserve fertilizers, pesticides, and other inputs & 60 & 63.16 \\
Reserve seed & 83 & 87.37 \\
\hline
\end{tabular}

Source: Author, 2018 
Factors Influencing the Households' Adaptation Under Natural Disaster Risk ...

Save fertilizers, pesticides, and other inputs: these are measures in heading face of disaster risks. Households did not reserve funds, but they bought inputs for production. At the time of low input prices in the year, people will buy inputs capable of preserving as seeds, fertilizers or pesticides, and these measures do not help household cope with disaster risk. In the event of a disaster risk, people can take reserves to produce together. The average rate is $63.16 \%$ of households regularly applied measures to a reserve of seed, fertilizer, and other inputs. That depends on the households' resources, so the poor households have less access.

Save seed production: Because households have long-standing experience in production so who's the risk prevention measures is diversity. However, the measures mainly focused on prevention and facing risks. Households still focus on essential risk prevention measures which include the seasonal adjustment of production combined with monitoring information regularly. Also, $87.37 \%$ of the households surveyed had applied measures "reserves seed production".

Thus, the households' cultivation used to 6 responses to natural disasters in reducing the damage includes (1) regularly monitor information; (2) changes seasonal calendar; (3) changes in crop varieties; (4) buy insurance; (5) save of fertilizer and pesticide inputs; (6) save seed production. People mainly used to precaution and face risks. A group of people used to preventive measures to avoid risks. A good deal of common is seasonally adjusted production of households, who have to deal with disaster risk in using the methods of cultivation present.

Adaptation with disaster risk in livestock and aquaculture

About natural disaster risks in the livestock sector, among forms were applied by people, there were 5 from 6 measures of prevention group. According to survey data, there was only one measure to face risks and nobody applied that. The percentage of households that implement response measures are shown in Figure 9. Current status of the household responded investigation with disasters in the livestock and fisheries shows that the two measures are prioritized implementing changes forms of livestock and crop adjustments. This is the simplest form of response that households can make in order to adapt. The actual survey showed that households choose early harvest for aquaculture (shrimp, fish, etc.) and sell livestock early (cattle, pigs,) to prevent and minimize the risk of damage caused by natural disasters. Again, households have adjusted measures that are suitable for animal husbandry. To cope with storms and floods, households also implemented a number of measures such as relocation of animals to another location, use the shield to avoid rain and the wind to protect livestock.

A number of households did not livestock, changed season calendar and built firm animal lodging that was low, ranging from 15-20\%. For families living in rural areas, their income based on agricultural production so if they left livestock, it would be a difficult measure. Abandoning livestock and crop mean household will lose part of family's income per year, and the transition to other forms of production, in order to earn extra income. Therefore, 
Factors Influencing the Households' Adaptation Under Natural Disaster Risk ...

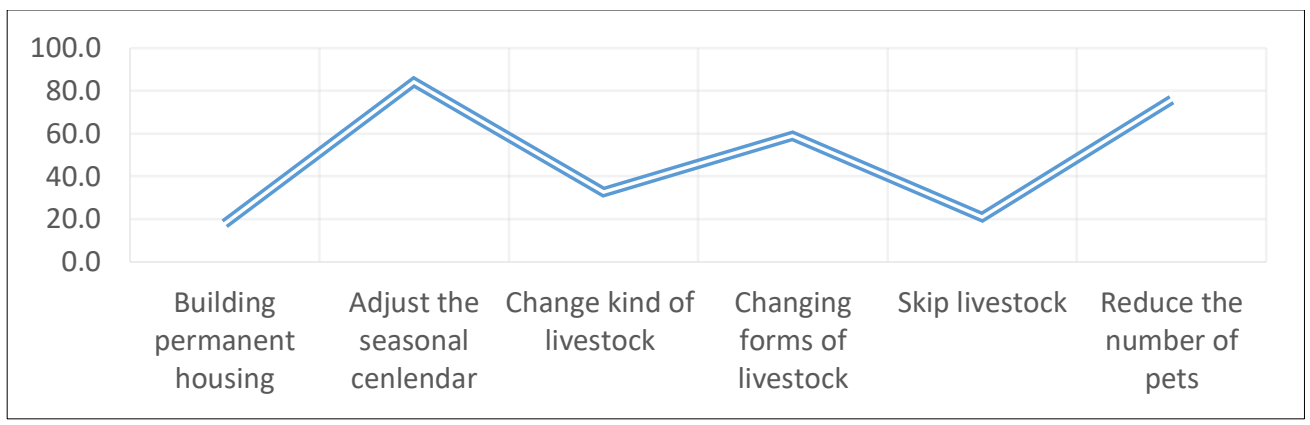

Figure 2 Adaptation of households with disaster risk in livestock and aquaculture Source: Author, 2018

only $20 \%$ of households applied negative measures. Conversely, the percentage of households applied "changing livestock" and "build durable animal houses" were not higher than because they didn't have capital.

For aquaculture, farmers sought to reinforce embankments before the storm occurs. They decreased in the aquaculture area and caught them before hurricane season. There was $72 \%$ of households said that in order to reduce the damage to people and property in the event of a large storm, they have been relocated to safe places to avoid storms such as schools, clinics, or the People's Committees of point's concentrated storm. However, some households leave behind about 1-2 members to protect and look after the house. $100 \%$ of households said that during rainstorms, households often send people to inspect the shore dress to try to correct promptly when incidents occur.

Adaptation with disaster risk in infrastructure and human

The measure that is most applicable protection is at a rate of up to $80 \%$ including food reserves, against housing ligament, tendon against the house. Food reserves, tendon, and ligament against anti barn houses are basic measures, common to be ready to face the risks, to be applied to households mainly based on folklore. That is the explanation for the popularity of these measures. At research area occurring storms, people fight against the door both outside and inside with iron wire, nylon wire, bamboo and wooden planks on the wooden walls, and bamboo walls, roof insert sandbags, roofed concrete. In addition, households also make moving property and household goods arrive safely to prevent and minimize risks caused by natural disaster.

3. Factors that affect to households' livelihoods in adapting to the risk of natural disasters impacts

\section{Factors from households}

According to the approach used, themes include the sustainable livelihoods framework developed by The Department for International Development UK (DFID, 2000) and the analysis and assessment of the state of vulnerability and ability to cope with risk disaster - VCA (Vulnerability and Capacity Assessment and Analysis) (2009), researcher found that at the household level there are 5 main groups of factors that affect the ability to cope 
Factors Influencing the Households' Adaptation Under Natural Disaster Risk ...

with the exploration of households with natural disaster risk. They include: (1) social capital; (2) natural capital; (3) financial capital; (4) physical capital; (5) human capital. In this study, the Logit model used to evaluate the factors influencing the households' adaptation under natural disaster risk in the coastal area. The dependent variable is the group of households respond with natural disaster risk (includes: no response and response). The independent variables are:

- Social capital:

(1) FI - Formal institutions (the number of organizations that engage family members);

(2) II - Institutional informal (number of close friends);

- Natural capital includes:

(3) LA - Land area of the household;

- Human capital variables measured by:

(4) LB - Number of labors in household;

(5) AG - The age of the household's head or decision-maker about coping in the family;

(6) G-The gender of the household's head or decision-maker about coping in the family;

(7) ED - The level of education of the household's head or decision-maker;

- Financial capital represented by variables:

(8) IC - Income of household per year;

The results (table 6) showed different levels of variables influence of response to decisions of the households to natural disasters.

When all 8 independent variables were considered together, they significantly predicted whether respond or not respond dependent by respondents, the pseudo R2 is 0.5161 in model summary tables. It means that approximately $51.61 \%$ of the variance in predicting the types of $y$ dependents.

The results in table 6 explained that three independent variables of II, LA and IC predicted significantly to the types of $y$ at significant level of 0.05 and two independent variables of $\mathrm{FI}$ and LB significantly at level 0.1 .

Table 6 Logit model results

\begin{tabular}{ccccccc}
\hline $\mathrm{y}$ & Coef. & Std. Err. & $\mathrm{z}$ & $\mathrm{P}>|\mathrm{z}|$ & \multicolumn{2}{c}{$[95 \%$ Conf. Interval] } \\
\hline FI & 1.500988 & .7814285 & 1.92 & 0.055 & -.0305836 & 3.03256 \\
II & .692825 & .3255874 & 2.13 & 0.033 & .0546854 & 1.330965 \\
LB & 1.024061 & .5507707 & 1.86 & 0.063 & -.0554295 & 2.103552 \\
AG & -.0834901 & .0530966 & -1.57 & 0.116 & -.1875575 & .0205773 \\
G & -.0981146 & .9109546 & -0.11 & 0.914 & -1.883553 & 1.687324 \\
ED & -.6567017 & 1.16443 & -0.56 & 0.573 & -2.938943 & 1.62554 \\
LA & .0012499 & .0005683 & .2 .20 & 0.028 & .0001361 & .0023637 \\
IC & .1861537 & .0897235 & 2.07 & 0.038 & .0102989 & .3620084 \\
Cons & -10.11486 & 4.332598 & -2.33 & 0.020 & -18.6066 & -1.623126 \\
\hline
\end{tabular}

Source: compiled by the author 
The model has formula:

$$
Y=1.500988 \mathrm{FI}+0.692825 \mathrm{II}+1.024061 \mathrm{LB}+0.0012499 \mathrm{LA}+0.1861537 \mathrm{IC}
$$

Social capital: For the probability of household respond, variables influenced II with $95 \%$ confidence level and FI significantly level 0.1. This may explain if the households had participating organizations, they will get more be informed through unions, associations such as the Youth Union, Women's Union, Farmers Union, Veterans Association, Society elderly. They have been integrated content propagation on disaster risk prevention and assistance to members in times of difficulty when they faced risks. Through modeling data, it showed that when households increase one more mainstream organization, we expect a 1.50988 increase in the log-odds of the ability to apply measures to respond to risk of natural disaster. The informal institutions such as close friends also have an impact on prevention response decisions of the household. However, the effects of II were not much, about 0.692825 for up one close. This can be explained to a household with an inferiority complex, they were often making friends with the household, who had the same their circumstances. They will support each other but it will be less effective because their life is very difficult the same. For residents, their trust affected the decision to respond. Actually, when the author was collecting data on the household's confidence in the state's policy to support, according to statistics they were confident about the policy content. However, a part of local policy enforcement is causing much annoyance to support farmers as false objects, support non-real-life situation of production (Petzold, \& Ratter, 2015).

Natural capital: Natural capital can affect the decisions of households. The land element was basic resources of the households, but the land area of the household is limited, so the area increases or decreases do not affect their decisions. From the data of the model it is shown that if the area increases $1 \mathrm{~m} 2$, it will increase by 0.0012499 probability decide to apply respond measures of the household in coastal areas at risk of natural disasters.

Financial capital: financial capital represents the variation of household savings in the year (Skees, 1999). Savings have an influence on decisions of household responses. Through the model, results showed that the variable IC affecting decisions of household responded, this variable was statistically significant at the $95 \%$ significance level. If the factor saves increase to 1 million VND, the probability decides of households respond with a natural disaster will increase about 0.186 of the time. This research showed that highincome households will accumulate more (Carter \& Ikegami, 2007) and that used to purchase fertilizers, change the seed...

Human capital: In the human capital, variables of the factor impact included: household's labor, the age of household's head, the gender of the household's head or person decision, the level of education of the household's head or the personal decision (Jacoby \& Skoufias, 1997; Holzmann, \& Jørgensen, 2001). All of the factors influencing decisions of households have significant at $95 \%$. However, household labor is factor significance in influencing decisions of households responding with statistically significant at level 0.1. That means if labor increases one person, the decision to apply measures of the households will increase 1.024 times of probability. 
Factors Influencing the Households' Adaptation Under Natural Disaster Risk ...

Thus, the main factors affecting the response of households to the risk of natural disaster, including (1) Fl; (2) II; (3) LB; (4) LA and (5) IC.

\section{Factors from community}

The organizations, groups, local associations have a very important role in that household living through the groups, associations of people, especially the farmers to interact and exchange experience in risk prevention strategies. On the other hand, through organizations, groups, local associations of people have shared mutual assistance in case of difficulties. Through the actual data it showed no significant difference between the groups of households participating or not participating groups in the incidence of natural disasters. However, in terms of the extent of damage we see clear differences between the households participating and households not participating involved in organized groups. The groups of households participating were losses average 17.8 million VND, while the households did not participate which were damaged 22.5 million VND.

The communities in rural areas have traditionally united to help each other from time immemorial, but there are communities of solidarity, and there are the communities which still have not been linked together in disaster prevention. These communities are often linked with a system of conventions, the convention is very tight in the village. Before the disaster, people help each other to transport their assets to the high places, to avoid damage. Many villages have several funds that are used to help families that are at risk.

Thus, the community is the main factor to influence people in the resilience of the people in coastal areas with risk of natural disasters. The communities, organizations, groups, and associations were sharing information and experience in preventing the natural disaster, especially the poor people (because of they limited access to modern sources of information such as TV, the internet, newspaper...). The survey data also showed that if households participated in groups, associations that were damaged to natural disaster risk lower than households did not involve in groups.

\section{Factors from government}

Programs are formed to respond to natural disasters through the Decision and Decree of the Government (hereinafter referred to as the response program) for supporting a portion of funds for damage caused by disaster. Specifically, cash support from 1 to 30 million VND/ ha for each level of damage and objects various crops; from 10 thousand VND to 4 million VND for a head of cattle and poultry; and from 3 to 60 million VND/ ha for each level of damage, and each kind of different fisheries affected by natural disasters through Decision No. 49/2012 / QD-TTg (November 8th, 2012) of Socialist Republic of Vietnam (2012). Support for loss of life and property due to natural disasters are specified in Article 12 of Decree No. 67/2007 / ND-CP ( from 2007 to 2/2010) and Paragraph 8 , Article 1, Decree No. 13/2010 / ND-CP (from 3/2010) which provides support from 1-1.5 million VND for the wounded; 3 to 4.5 million VND for people were dead or missing; 5-7 
Factors Influencing the Households' Adaptation Under Natural Disaster Risk ...

million VND for the collapse, drop, drift, severely damaged; and 5-7 million VND for the displaced families of emergency due to the risk landslides and flash floods.

Besides the initial response, the program has focused on disaster prevention strategies through removing temporary housing for households in regions frequently occurring natural disasters (Decision No. 167/2008 / QD-TTg); raising public awareness about disaster risk management (Decision No. 1002 / QD-TTg dated 13/07/2009).

The response to this program has initially contributed to the rural population in areas of natural disasters frequently occur with partial funding to overcome the first step in production losses as well as losses on the basis of Infrastructure. Additionally, these programs also contribute initially to raise awareness to the people about disaster risks and prevention.

However, standing at a different angle, the effectiveness of policy responses based on the Decision and Decree is not high and has limited response capacity of the people in rural areas at risk of natural disasters. These factors have limited response from the program and are shown through the following issues:

(1) The overlap and spread of these programs have limited response capacity to cope with the people, especially the people.

(2) The procedures for implementing the program is complex response, low support levels, speed up the slow disbursement efficiency is not high response.

(3) Capacity policy enforcement officials, especially the commune staff should effectively limited enforcement is not high, adaptive capacity of people has not improved.

\section{Other factors}

As discussed in the section above, the adaptive capacity of household at risk of natural disasters depends on factors including social capital, natural capital, financial capital, physical capital, human capital and the policies of the state. However, there are many other factors, though not directly affected or directly affected but had not affected major factors as the cultural characteristics of each ethnic group, region, supporting organizations and individuals inside and outside country (Djalante, Holley, \& Thomalla, 2011).

The cultural characteristics affect the ability of people to respond to natural disasters. Cultural characteristics affect the ability to acquire knowledge on disaster prevention. Misconceptions about disaster phenomena are not abandoned due to the longstanding formation.

The support of NGOs and other private institutions: In recent years, in disadvantaged areas, organizations helped households whose affected by natural disasters. The assistance such as food, clothing, seeds, and fertilizers helped people experiencing difficulties in certain periods during disasters. But the only help solves the immediate problem or face measures that do not have measures to help people transfer or avoid 
Factors Influencing the Households' Adaptation Under Natural Disaster Risk ...

risks. With non-governmental organizations, NGOs have coordinated measures to help people with sustainable development measures. However, resources of organizations with good model's limit should not be replicated (Spalding, Ruffo, Lacambra, Meliane, Hale, Shepard, \& Beck, 2014).

Thus, the support of individuals, organizations and socio-economic characteristics, the culture of each region also affects the ability of household to respond to the resilience of household.

\section{Conclusion}

Natural disaster risk caused serious (i) loss and damages to houses, (ii) agricultural production, (iii) fishing income, and (iv) aquaculture income of households. Therein, aquaculture sub-sector in the selected communes was the most vulnerable to typhoon surge, flood. Coastal erosion did not affect much the coastal households. But saltwater intrusion affected mostly agriculture and freshwater aquaculture. Results showed that saltwater intrusion seems to be one of the major natural disaster risks together with typhoons/floods affecting livelihoods and lives of the coastal households. Thus, there is a need to build up an effective agricultural and fishery insurance service to provide more choices for the local households to cope and adapt to natural disaster risk.

The findings from the research show the main factors affecting the resilience of the household to natural disaster risks are (1) FI; (2) II; (3) TR; (4) LA and (5) IC. The community is a big factor to influence people in the resilience of the household in the coastal areas at risk of natural disasters. Communities, organizations, groups, and associations were sharing information and experience with households in the coastal areas. The survey data also showed that households participate in groups, associations, the damage to natural disaster risk are also lower than households not involved. The support of individuals, organizations and socio-economic characteristics, the culture of each region also affects the ability of people to respond to the resilience of people to disaster risks. The pattern of non-governmental organizations works well with people, but also in the area of influence narrow scale, need replication in suitable areas to help farmers improve their lives thereby improving application city.

\section{References}

ADPC. (2003). Climate Change and Development in Vietnam: Agriculture and Adaptation for the Mekong Delta Region. Eschborn: Deutsche Gesellschaft für. Received from http://cforn.mpi.gov.vn/Portals/0/Upload/report/MienNam/4 1 GTZ\%20$\% 20$ Climate $\% 20$ Change $\% 20$ and $\% 20$ Development $\% 20$ in $\% 20$ Vietnam.pdf

Brammer, H. (2013). Bangladesh's dynamic coastal regions and sea-level rise. Climate Risk Management 1 (51-62). https://doi.org/10.1016/j.crm.2013.10.001

Bryant, E. A. (1993). Natural hazards. Cambridge University Press. 
Phong, Mai, \& Aditto

Factors Influencing the Households' Adaptation Under Natural Disaster Risk ...

CARE in Vietnam. (2015). Making it Count. Integrating Gender into Climate Change and Disaster Risk Reduction: A practical how-to guide. UN Women, GIZ. Received from https://reliefweb.int/report/viet-nam/making-it-count-integrating-gender-climatechange-and-disaster-risk-reduction

Carter, M. R. \& Ikegami, M. (2007). Looking Forward: Theory-Based Measures of Chronic Poverty and Vulnerability. Chronic Poverty Research Centre Working Paper No. 94. https://dx.doi.org/10.2139/ssrn.1629286

Chaudhry, P., \& Ruysschaert, G. (2007). Climate Change and Human Development in Viet Nam. Human Development Report 46, 1-18. Human Development Report Office Occasional Paper. UNDP. Received from http://hdr.undp.org/en/content/climate-change-andhuman-development-viet-nam

Creswell, J. (2003). Research Design: Qualitative, Quantitative, and Mix Methods Approaches. SAGE Publications.

Dabi, D. D., Nyong, A. O., Adepetu, A. A., Ibemegbulem, I. (2007). Past, Present and Future Adaptaion by Rural Households of Northern Nigeria. In J. A. Neil Leary, Climate Change and Adaptation (p. 91). London.

Dazé, A., Ambrose, K., \& Ehrhart, C. (2009). Climate Vulnerability and Capacity Analysis Handbook. CARE International. Received from https://www.care.org/sites/default/files/documents/CC-2009CARE_CVCAHandbook.pdf

Dercon, S. (2002). Shocks and Poverty during Economic Reform: Evidence from Rural Ethiopia. Paper prepared. IMF Conference on Macroeconomic Policies and the Poor in Washington, DC, March 14-15. Received from

https: / / www.google.com/url? sa =t\&rct=j\&q=\&esrc=s\&source=web\&cd=1\&cad $=$ rja \&uact $=8 \&$ ved $=2$ ahUKEwjxwLtl67pAhUYcCsKHVnGB2UQFjAAegQIARAB\&url=https $\% 3 \mathrm{~A} \% 2 \mathrm{~F} \% 2 \mathrm{Fwww.imf.or}$ $\mathrm{g} \% 2 \mathrm{~F} \sim 02 \mathrm{Fmedia} \% 2 \mathrm{FWebsites} \% 2 \mathrm{FIMF} \% 2$ Fimportedevents $\% 2$ Fexternal $\% 2$ Fnp $\% 2$ Fres $\% 2$ Fseminars $\% 2 F 2002 \% 2$ Fpoverty $\% 2 \mathrm{~F}$ sdpdf.ash x\&usg=AOvVaw2voYIR2R - emm214mCPIDi

Dercon, S. H. (2004). Health, Shocks and Poverty Persistence, in Insurance Against Poverty. Oxford University Press.

DFID. (2000). Sustainable Livelihoods Guidance Sheets. London: Department for International Development UK. Retrieved from http://www.livelihoods.org/info/info guidancesheets.html

Djalante, R., Holley, C., \& Thomalla, T. (2011). Adaptive Governance and Managing Resilience to Natural Hazards. International Journal of Disaster Risk Science, 2(4), 1-14. https://doi.org/10.1007/s13753-011-0015-6

Goulden, M. (2011). Accessing diversification, networks and traditional resource management as adaptations to climate extremes. In I. L. W. Neil Adger, Adapting to Climate Change (p. 448). Cambridge Universtiy Press.

Greene, W. H. (2012). Econometric Analysis (Seventh ed.). Boston: Pearson Education.

Hardaker, J. R. (1997). Coping with Risk in Agriculture. Oxon, UK: CAB International.

Hiwasaki, L., Lunab, E., Syamsidik, \& Shawd, R. (2014). Process for integrating local and indigenous knowledge with science for hydro-meteorological disaster risk reduction and climate change adaptation in coastal and small island communities. International Journal of Disaster Risk Reduction, 10(A), 15-27. https://doi.org/10.1016/j.ijdrr.2014.07.007

Holzmann, R., \& Jørgensen, S. (2001). Social Risk Management: A New Conceptual Framework for Social Protection, and Beyond. International Tax and Public Finance 8(4), 529-556. 
Phong, Mai, \& Aditto

Factors Influencing the Households' Adaptation Under Natural Disaster Risk ...

https: / / econpapers.repec.org/scripts/redir.pf?u $=$ https $\% 3 \mathrm{~A} \% 2 \mathrm{~F} \% 2 \mathrm{Fdoi} .0 \mathrm{rg} \% 2 \mathrm{~F} 10.1$ 023\%252FA\%253A1011247814590;h=repec:kap:itaxpf:v:8:y:2001:i:4:p:529-556

Jacoby, H. G., \& Skoufias, E. (1997). Risk, Financial Markets, and Human Capital in A Developing Country. Review of Economic Studies 64(3), 311-336. https://doi.org/10.2307/2971716

Kleinbaum, D. G., Kupper, L. L., Muller, K. E., Nizam, A. (1998). Applied Regression Analysis and Other Multivariable Methods. Duxbury Press.

McElwee, P. (2010). The Social Dimensions of Adaptation to Climate Change in Vietnam. Development and climate change discussion paper; no. 17. Washington, DC: World Bank. Received from http://documents.worldbank.org/curated/en/955101468326176513/The-socialdimensions-of-adaptation-of-climate-change-in-Vietnam

Nhu O. L., Thuy N. T. T., Wilderspin I. \& Coulier, M. (2011), A preliminary Analysis of flood and storm disaster data in Vietnam Global Assessment Report on Disaster Risk Reduction, UNDP: Viet Nam.

OECD. (2000). OECD Annual Report 2000.

OECD. (2008). An Overview of Policy Measures for Risk Management. TAD/CA/APM/WP(2008)24/Final.

Osman-Elasha, B. \& Sanjak, E. (2008). "Livelihoods and Drought in Sudan", In Climate Change and Vulnerability, Leary Et. Al. [Editors]. Pp 239-253. Earthscan Publications Ltd.

Petzold, J., \& Ratter, B. M. W. (2015). Climate change adaptation under a social capital approach - An Analytical Framework for Small Islands. Ocean \& Coastal Management, 112, 36-43. https://doi.org/10.1016/i.ocecoaman.2015.05.003

Roshanka, R., \& Ruben, J. (2018). Climate Change, Coasts and Coastal Risk. Journal of Marine Science and Engineering, 6(4), 141-145. https://doi.org/10.3390/jmse6040141

Sajise, A.J.U., Ramirez, P.J.R., Zamora, G.J., Herbosa, J.M.R., Agbon, A.B., Nguyen V.D (2017). EEPSEA Research Report No. 2017-RR15. Economy and Environment Program for Southeast Asia, Laguna, Philippines. Received from https://www.worldfishcenter.org/content/intra-household-impacts-climate-hazardscoastal-communities-cross-country-perspective- 0

Sales, R. F. M. (2009). Vulnerability and Adaptation of Coastal Communities to Climate Variability and Sea-level Rise: Their Implications for Integrated Coastal Management in Cavite City, Philippines. Ocean \& Coastal Management, 52(7), 395-404. https://doi.org/10.1016/i.ocecoaman.2009.04.007

Skees, J. (1999). Opportunities for improved efficiency in risk sharing using capital markets. American Journal of Agricultural Economics, 81(5), 1228-33.

Spalding, M. D., Ruffo, S., Lacambra, C., Meliane, I., Hale, L. Z., Shepard, C. C., \& Beck, M. W. (2014). The role of ecosystems in coastal protection: Adapting to climate change and coastal hazards. Ocean \& Coastal Management, 90, 50-57. https://doi.org/10.1016/i.ocecoaman.2013.09.007

The World Bank (2001). World Development Report 2000/2001. Attacking Poverty, New York.

The World Bank (2004). Natural Disasters: Counting the Cost.

UNDP. (2015). Traditional Knowledge and Experience in Natural Disaster Prevention. Received from http://www.vn.undp.org/content/vietnam/en/home/countryinfo/\#Challenges

UNISDR. (2013). The Global Assessment Report on Disaster Risk Reduction. Received from 
Phong, Mai, \& Aditto

Factors Influencing the Households' Adaptation Under Natural Disaster Risk ...

http://www.preventionweb.net/english/hyogo/gar/2013/en/home/GAR 2013/GA R 2013 2.html.

Warrick, R. A. (1980). Drought in the Great Plains: a case study of research on climate and society in the USA. USA, in J. Ausubel and A. Biswas, Eds. Climatic Constraints and Human Activities, Oxford; Pergamon Press, 93-124. Received from

http://scholar.google.com/scholar lookup?\&title=Climatic $\% 20$ Constraints $\% 20$ and $\%$ 20 Human $\% 20$ Activities\&pages $=93$ -

124\&publication year $=1980$ \&author $=$ Warrick $\% 2 \mathrm{CR} . \% 20 \mathrm{~A}$. 